\title{
The emerging role of WISP proteins in tumorigenesis and cancer therapy
}

\author{
Yi Liu' ${ }^{1}$, Yizuo Song ${ }^{1}$, Miaomiao Ye ${ }^{1}$, Xiaoli Hu ${ }^{1}$, Z. Peter Wang ${ }^{2,3,4^{*}}$ and Xueqiong Zhu ${ }^{1 *}$
}

\begin{abstract}
Accumulated evidence has demonstrated that WNT1 inducible signaling pathway protein (WISP) genes, which belong to members of the CCN growth factor family, play a pivotal role in tumorigenesis and progression of a broad spectrum of human cancers. Mounting studies have identified that WISP proteins (WISP1-3) exert different biological functions in various human malignancies. Emerging evidence indicates that WISP proteins are critically involved in cell proliferation, apoptosis, invasion and metastasis in cancers. Because the understanding of a direct function of WISP proteins in cancer development and progression has begun to emerge, in this review article, we describe the physiological function of WISP proteins in a variety of human cancers. Moreover, we highlight the current understanding of how the WISP protein is involved in tumorigenesis and cancer progression. Furthermore, we discuss that targeting WISP proteins could be a promising strategy for the treatment of human cancers. Hence, the regulation of WISP proteins could improve treatments for cancer patients.
\end{abstract}

Keywords: Cancer, WISP, Oncogene, Drug, Targets, Therapy

\section{Introduction}

The connective tissue growth factor/cysteine-rich 61/ nephroblastoma overexpressed $(\mathrm{CNN})$ growth factor family includes cysteine-rich 61/CCN1 (CYR61), connective tissue growth factor/CCN2 (CTGF), nephroblastoma overexpressed/CCN3 (NOV), and WNT1 inducible signaling pathway protein (WISP) genes [1]. WISP genes were named because they are upregulated in mammary epithelial cells transformed by the Wnt-1 oncogene [2]. There are three identified WISP genes, which includeWISP1/CCN4, WISP2/CCN5, and WISP3/CCN6. $\mathrm{CCN}$ proteins have four highly conserved cysteine-rich motifs as follows: the N-terminal motif, the von Willebrand factor-like (VWC) motif, the thrombospondin type 1 (TSP-1) motif, and the carboxy-terminal (CT) motif [3] (Fig. 1). The N-terminal motif consists of the first 12 cysteine residues and the IGF binding consensus

\footnotetext{
*Correspondence: zwang6@bidmc.harvard.edu; zjwzzxq@163.com ${ }^{1}$ Department of Obstetrics and Gynecology, The Second Affiliated Hospital of Wenzhou Medical University, No. 109 Xueyuan Xi Road, Wenzhou 325027, Zhejiang, China

${ }^{4}$ Department of Pathology, Beth Israel Deaconess Medical Center, Harvard Medical School, 330 Brookline Ave, Boston, MA 02215, USA Full list of author information is available at the end of the article
}

sequence (GCGCCXXC). VWC and TSP1 motifs could play a role in cell-cell interactions and angiogenesis inhibition. The CT motif forms a "cysteine knot", which has been observed in other signaling peptides [3]. WISP2 lacks the CT module, which might lead to different functions than WISP1 and WISP3.

WISP1-3 genes are localized on the human chromosome $8 \mathrm{q} 24.1-8 \mathrm{q} 24.3,20 \mathrm{q} 12-20 \mathrm{q} 13$, and $6 \mathrm{q} 22-6 \mathrm{q} 23$, respectively [2]. The role of WISP1-3 in human cancer is controversial. For instance, the RNA levels of WISP1 and WISP3 have been shown to be overexpressed in human colon tumors compared with normal mucoma, whereas WISP2 RNA expression has been shown to be reduced in colon tumors [2]. Another study reported that WISP1 mRNA expression was detected in normal and transformed breast cell lines. However, WISP2 mRNA was undetected in normal breast epithelial cells, but was observed in tumor-derived cell lines [4]. These reports suggest that WISP genes could have diverse functions in various human cancers. In the following sections, we highlight the physiological function of WISP proteins in a variety of human tumors. We further clarify the molecular mechanism underlying WISP-involved tumorigenesis and cancer progression. We also discuss whether 


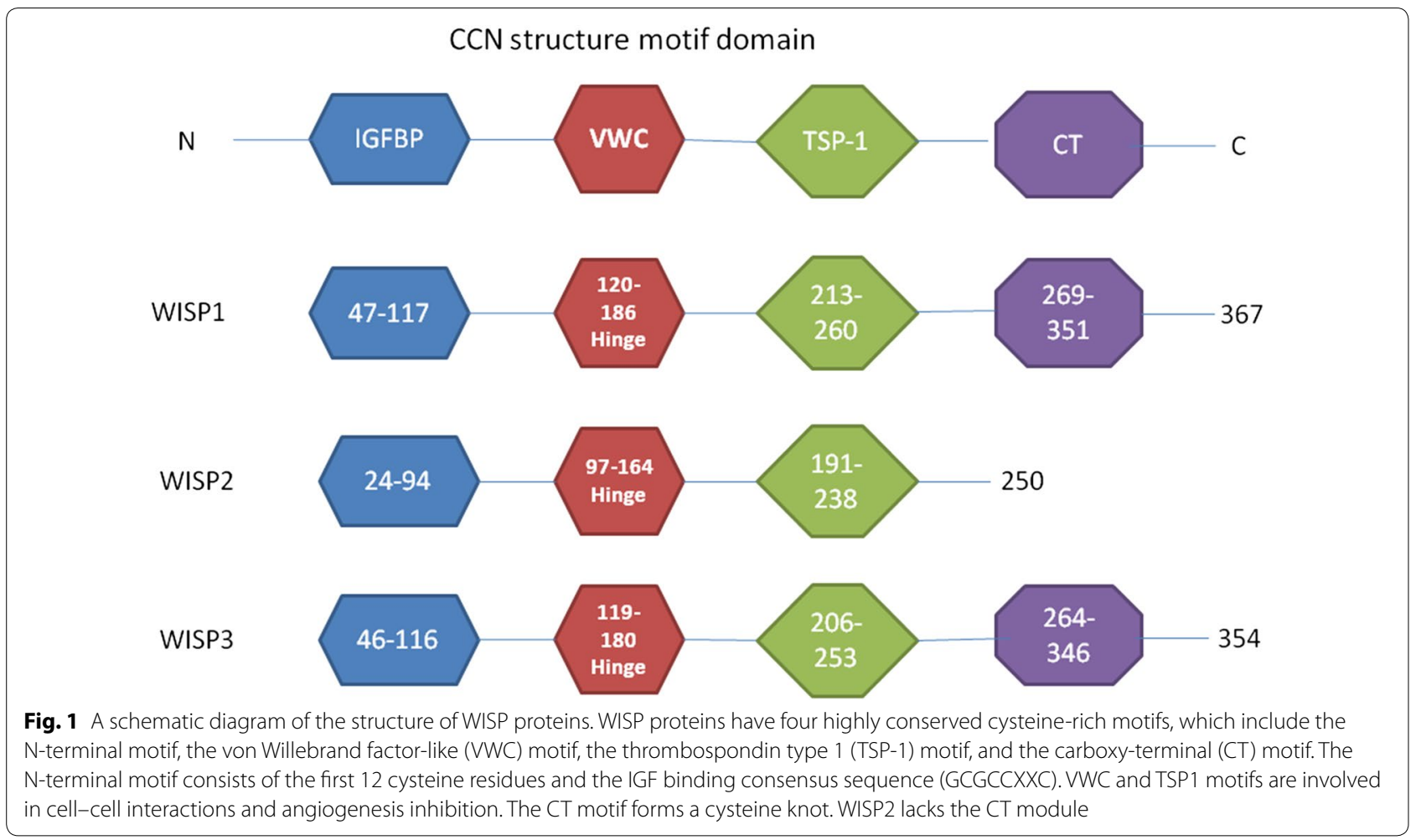

targeting WISP could offer a promising strategy for the treatment of human cancers (Figs. 2, 3, 4).

\section{Role of WISP in human cancers}

\section{Breast cancer}

WISP1 has been reported to play an important role in breast cancer cells [4]. Xie et al. noticed the overexpression of WISP1 in primary breast tumors. Moreover, WISP1 expression is correlated with tumor stage, tumor size, and lymph node metastasis in breast cancer patients [5], suggesting that WISP1 exerts pro-tumorigenic functions in breast cancer. Consistent with this finding, Chiang et al. found similar results, in which WISP1 was highly expressed in breast cancer patients. Using an in vitro model, recombinant WISP1 treatment increased cell proliferation of breast cancer cells [6]. Overexpression of WISP1 enhanced cell growth and promoted tumor growth in mice. Strikingly, overexpression of WISP1 induced epithelial-mesenchymal transition (EMT) and changed the expression of EMT markers in breast cancer cells [6]. For example, WISP1 overexpression inhibited E-cadherin, but increased $\mathrm{N}$-cadherin, Snail, and $\beta$-catenin. WISP1 upregulation also repressed the expression of the tumor suppressor NDRG1 in breast cancer cells [6]. In support of the oncogenic role of WISP1, one report demonstrated that increased WISP1 was associated with oncogenic transformation in invasive breast cancer. Importantly, WISP1 could be a paracrine inhibitor of type 1 cell-mediated immunity via suppression of IL-12 signaling and promotion of type 2 immunity to promote the transformation of invasive breast cancer [7]. Furthermore, WISP1 was increased after PTEN knockdown in MCF-7 breast cancer cells, leading to the promotion of cell migration and invasion [8]. Interestingly, another study showed that WISP-1 transcripts were observed in lower levels in breast cancer patients with poor prognosis [9], indicating that WISP1 seems to act as tumor suppressor in breast cancer. Consistent with this finding, the level of WISP1 expression was much lower in metastatic breast cancer compared to nonmetastatic breast cancer, suggesting that WISP1 may serve as an indicator of the risk of metastasis in breast carcinoma [10]. Therefore, an in-depth investigation is required to determine the biological and physiological functions of WISP1 in breast cancer.

WISP2 expression was markedly increased in human breast cancer cells after $17 \beta$-estradiol (E2) treatment. This increase in WISP2 mRNA expression was completely inhibited by coincubation with an anti-estrogen agent, indicating that WISP2 could be directly regulated by estrogen receptors in human breast cancer cells [11]. This group further defined WISP2 as a secreted protein and as a marker of estrogen exposure in breast cancer cells [12]. WISP2 induction is highly specific for 


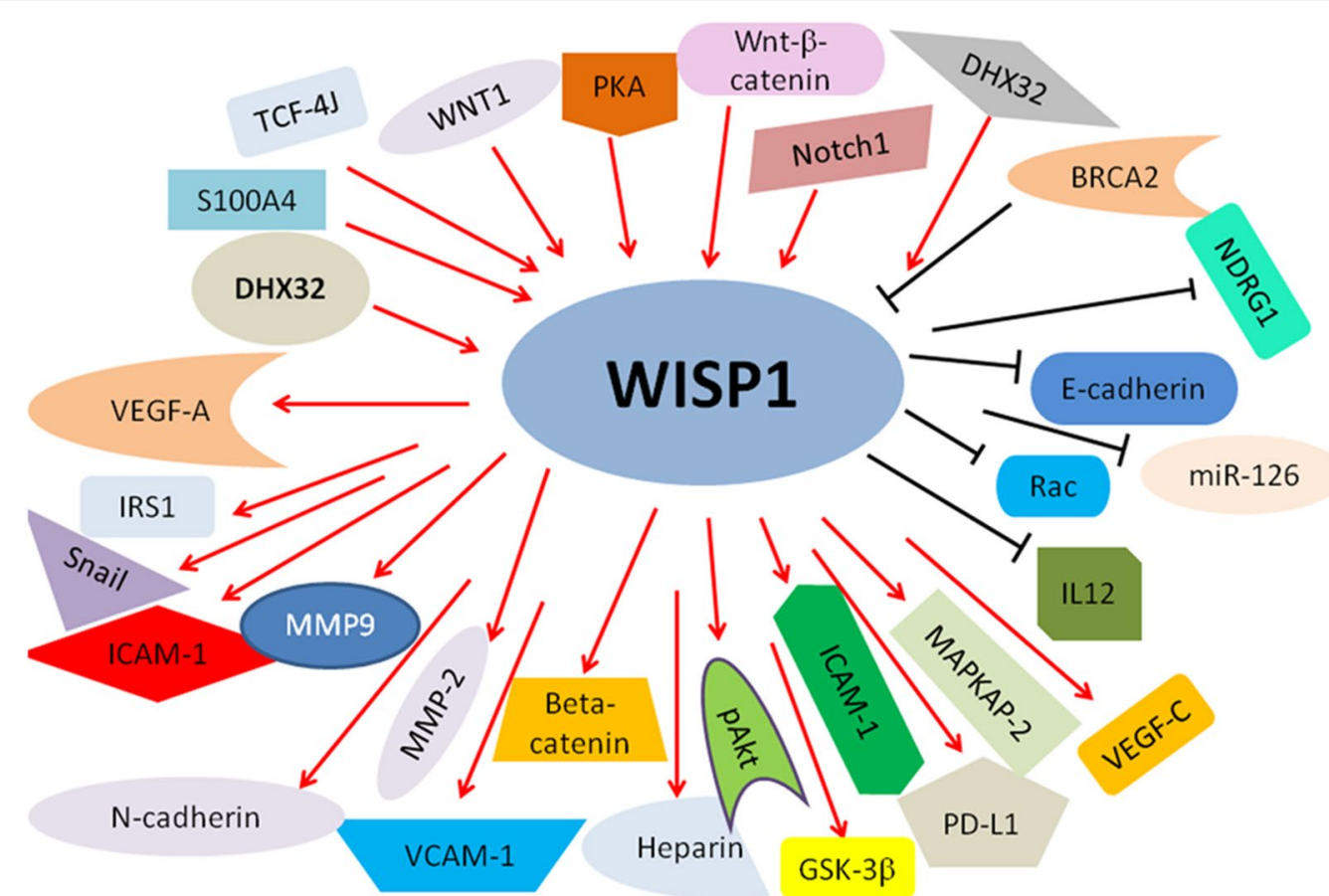

Fig. 2 Illustrated pathways for WISP1-regulated downstream targets and the identified upstream regulators. "Arrow to WISP" $\rightarrow$ means "activating WISP"; "Arrows from WISP to $\rightarrow$ targets" means "activating targets". "Blockade to WISP" means—"inhibiting WISP"; "Blockade from WISP to targets" meaning-"inhibiting targets"

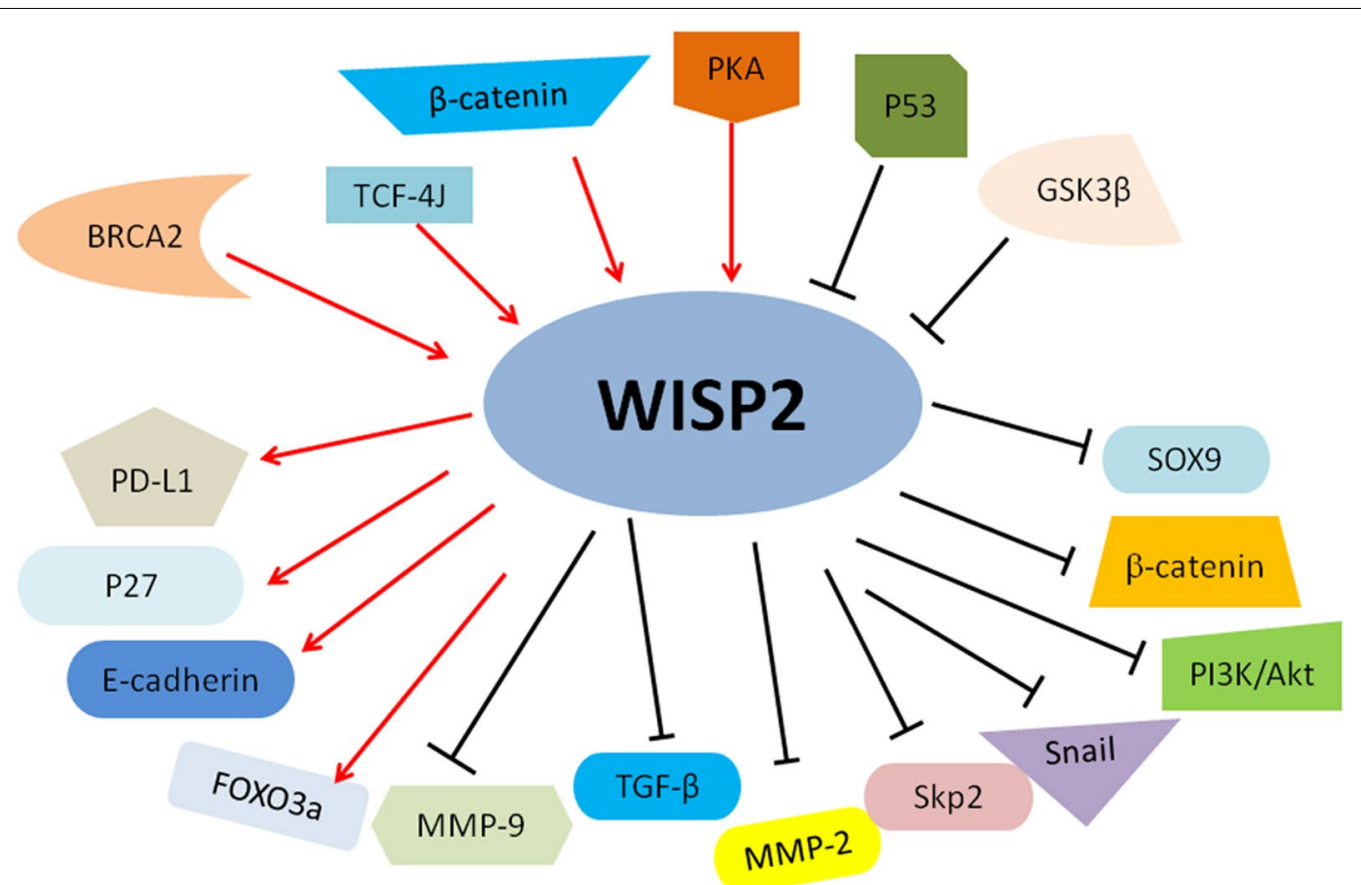

Fig. 3 Illustrated pathways for WISP2-regulated downstream targets and the identified upstream regulators. "Arrow to WISP" $\rightarrow$ means "activating WISP"; "Arrows from WISP to $\rightarrow$ targets" means "activating targets." "Blockade to WISP" means—."inhibiting WISP"; "Blockade from WISP to targets" meaning $\rightarrow " i n h i b i t i n g ~ t a r g e t s "$ 


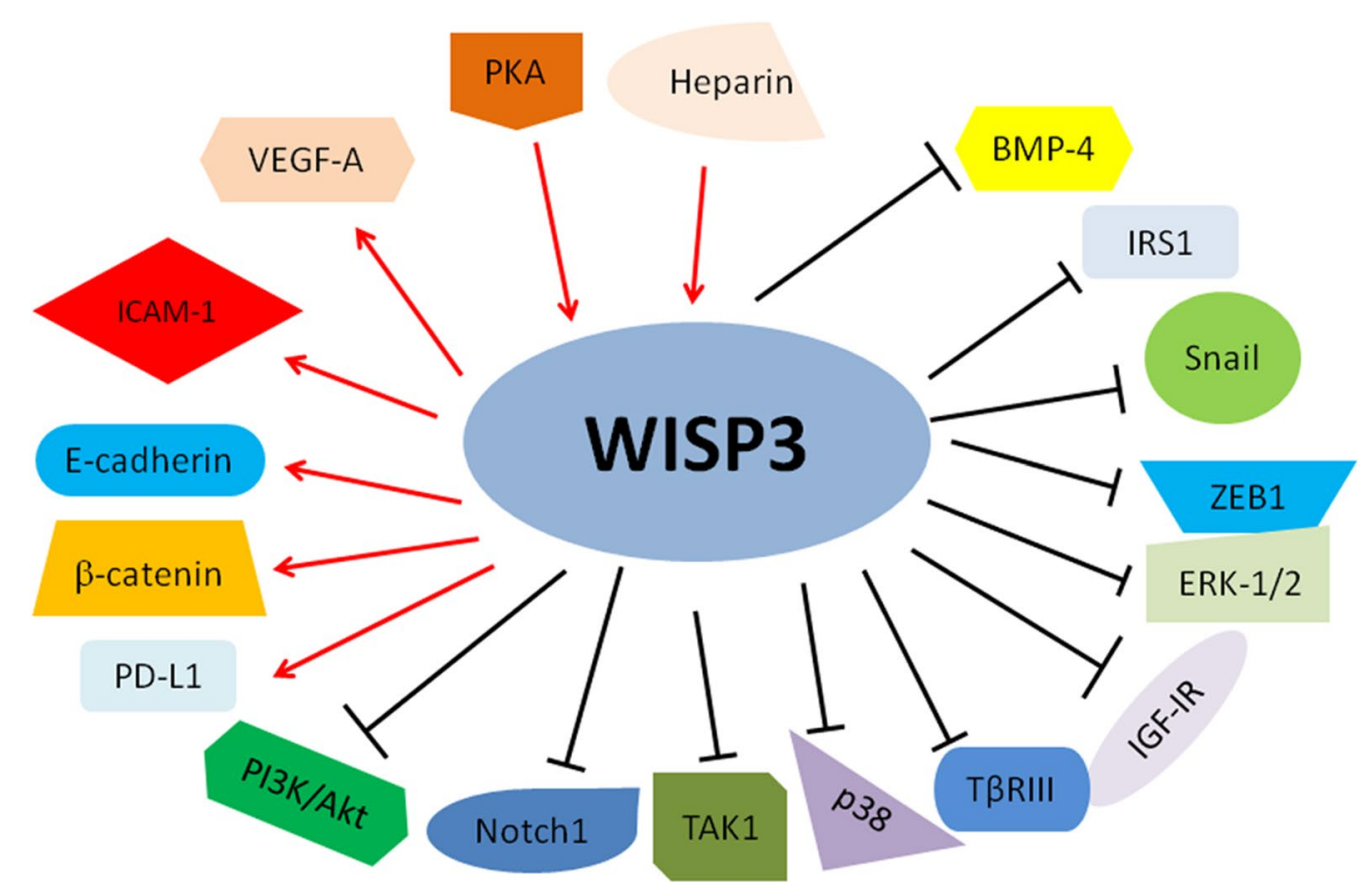

Fig. 4 Illustrated pathways for WISP3-regulated downstream targets and the identified upstream regulators. "Arrow to WISP" $\rightarrow$ means "activating WISP"; "Arrows from WISP to $\rightarrow$ targets" means "activating targets". "Blockade from WISP to— targets" meaning "inhibiting targets"

hormones that interact with the estrogen receptor [12]. Consistent with this report, the WISP2 gene exhibited estrogen- and progesterone-inducible expression and regulation of tumor cell proliferation in breast cancer cells [13]. WISP2 expression has been induced by protein kinase A (PKA) activators in human breast cancer cells [14]. Subsequently, one study confirmed that WISP2 expression can be modulated by serum and is correlated with serum-induced cell growth in breast cancer cells, demonstrating that WISP2 is responsible for serum stimulation and enhances cell growth in breast cancer [15]. WISP2 expression has been found to be highly overexpressed in human breast cancer MCF-7 cells, whereas it was undetectable or minimally detectable in nontransformed human mammary epithelial cells [15]. Along with this finding, WISP2 exhibits high levels of expression in breast cancer patients at late stages with metastasis, suggesting that WISP2 could be an oncoprotein in breast cancer [9].

One study showed that WISP2 expression is undetectable in normal and poorly differentiated breast cancer samples, but it is increased in noninvasive breast lesions [16]. The WISP2 expression level is inversely correlated with lymph node metastasis. In support of this correlation, WISP2 was found to be a negative regulator of migration and invasion via regulation of Snail, E-cadherin, matrix metalloproteinase-2 (MMP-2), and MMP-9 in breast cancer cells [16]. This study implied that WISP2 overexpression could have therapeutic implications for anti-invasion in breast cancer. Mechanistically, the overexpression of p53 mutants has been shown to inhibit WISP2 expression, enhance cell invasiveness, and induce EMT in ER-positive noninvasive breast tumor cells [17]. Notably, the depletion of WISP2 increased PD-L1 levels in breast cancer cells. The depletion of ZEB1 or overexpression of miR-200 family members in breast cancer cells with WISP2 depletion decreased PD-L1 expression levels. Inhibition of PD-L1 restored the susceptibility of resistant cells with WISP2 depletion to CTL-mediated killing apoptosis [18]. Additionally, the activation of WISP2 caused cell cycle arrest at the G1/G1 phase, reduced cell growth, and slowed tumor growth in a xenograft model via p27 upregulation and relocalization from the cytoplasm to the nucleus in breast cancer cells [19]. A mechanistic study showed that WISP2 suppresses Skp2 expression and subsequently stabilizes p27 accumulation, inducing FOXO3a expression and activity via shifting to the nucleus from the cytoplasm. Moreover, WISP2 
inhibits the PI3K/Akt signaling pathway to dephosphorylate FOXO3a for its nuclear relocalization and activation [19]. These reports demonstrate that activation of WISP2 could have the potential for breast cancer treatment. Another study showed that knockdown of WISP2 promoted EMT in breast cancer cells, whereas overexpression of WISP2 reversed cells toward a more differentiated phenotype. Overexpression of WISP2 reduced cell proliferative and invasive phenotypes in breast cancer cells. This demonstrated that WISP2 could be involved in tumor cell invasion and metastasis in breast cancer [20]. This group further discovered that loss of WISP2 enhances the stem-like phenotype of cancer cells, which is characterized by high Cd44 expression, high aldehyde dehydrogenase (ALDH) activation and mammosphere development in breast cancer cells [21]. Consistently, WISP2 depletion increased the expression of the stem cell markers Nanog and Oct3/4, and activated the TGF- $\beta$ pathway in breast cancer cells [21].

As early as 1999, WISP3 was identified to be underexpressed in inflammatory breast cancer (IBC) cell lines [22]. Subsequently, many studies further confirmed that WISP3 is downregulated in breast cancer cells and breast cancer tissues [23-25]. Consistent with these observations, inhibition of WISP3 expression promoted cell growth, invasion, and metastasis and protected cells from apoptosis and anoikis [25-28]. Kleer et al. revealed that WISP3 inhibits the expression of IGF-IR and its downstream targets, IRS1 and ERK-1/2, leading to cellular growth inhibition of breast cancer cells [29]. Similarly, inhibition of WISP3 expression induced EMT, enhanced cell growth, increased motility and invasiveness, and sensitized cells to IGF-1 treatment in human mammary epithelial cells [26]. Suppression of WISP3 has been shown to decrease the expression of E-cadherin via inducing Snail and ZEB1 in breast epithelial cells [25]. Consistent with this result, another research group identified that WISP3 inhibits ZEB1triggered EMT and invasion through attenuation of IGF-1 receptor signaling in breast cancer [30]. Huang et al. found that low expression of WISP3 is correlated with high levels of phospho-Akt-1 in invasive breast carcinomas. WISP3 knockdown has been shown to activate the phosphatidylinositol 3-kinase (PI3K)/ Akt pathway to enhance the survival of breast cancer cells [28]. Notably, WISP3 suppresses the invasion and metastasis of breast cancer cells through the inhibition of the bone morphogenetic proteins (BMP4) signaling pathway and subsequent suppression of TAK1 and p38 kinases [31]. Later, this group highlighted that knockdown of WISP3 can disrupt the acinar organization of breast cells via overexpression of type III TGF- $\beta$ receptor (T $\beta$ RIII), suggesting that WISP3 plays a role in maintaining acinar organization in breast tissue [32]. In a recently published study, WISP3 overexpression was sufficient to reverse EMT to MET and to reduce tumor initiating cells (TICs) via downregulating Notch1 signaling in breast cancer cells [33]. Strikingly, the results from a mouse model of mammary epithelial-specific WISP3 deletion indicated that the depletion of WISP3 in mice caused invasive high grade mammary carcinomas, which recapitulated human metaplastic breast carcinomas [34]. This mouse model provided direct evidence for the tumor suppressive role of WISP3 in breast cancer.

\section{Hepatocellular carcinoma (HCC)}

Emerging evidence has revealed that the WISP family is critically involved in hepatocellular tumorigenesis. For example, WISP1 and WISP3 have been reported to be expressed in HCC cell lines. Moreover, two new variants generated by alternative splicing of WISP1 and WISP3 have been discovered, although the important function of these variants has not been elucidated in HCC [35]. Using c-Myc/E2F1 transgenic mouse model-driven liver cancer, the $\mathrm{Wnt} / \beta$-catenin pathway, including its downstream targets, such as WISP1 and glutamine synthetase, has been activated, which was shown to confer cell growth in HCC [36]. One group provided direct evidence of WISP1 biological function in HCC cells. Inhibition of WISP1 suppressed cell proliferation, migration, and adhesion, but enhanced apoptosis via downregulation of pAkt, glycogen synthase kinase- $3 \beta$ (GSK-3 $\beta$ ), and MMP-2 in HCC [37]. Interestingly, WISP1 was observed to be decreased in HCC samples and was closely associated with clinical features, such as invasion, pTNM stage, and patient survival, indicating that WISP1 may have a potential tumor suppressive function in HCC [38]. Undoubtedly, further studies are necessary to clarify the physiological function of WISP1 in $\mathrm{HCC}$ by in vitro and in vivo experiments.

Two studies reported that the hepatitis $C$ virus core protein promotes cell growth via upregulation of Wnt-1 expression and its downstream gene WISP2 in HCC cells, indicating that WISP2 could play a potential role in HCC cell growth $[39,40]$. HBx mutants, which frequently occur in hepatitis B virus (HBV)-related hepatocellular carcinoma, have been reported to promote cell proliferation and migration through the activation of the $\mathrm{Wnt} / \beta$-catenin signaling pathway [41]. Specifically, HBx mutants increased and stabilized $\beta$-catenin 
levels via inhibition of GSK3 $\beta$ in HCC cells, leading to the upregulation of WISP2 and c-Myc [41]. Similarly, the T-cell factor 4 (TCF-4) transcription factor protein has been shown to regulate the $\mathrm{Wnt} / \beta$-catenin signaling pathway in human cancers $[42,43]$. The expression level of WISP2 is enhanced in HCC cells overexpressing TCF-4J (TCF-4 isoform J), suggesting that WISP2 could be involved in HCC progression [44]. One group found that WISP2 expression does not differ between HCC samples and normal liver tissues, while WISP3 was only detected in a few HCC samples [37]. Therefore, it is necessary to clarify the role of WISP2 and WISP3 in HCC in the near future.

\section{Colon cancer}

Increasing evidence has supported the important roles of the WISP family in colon tumorigenesis. For example, WISP1 has been found to be upregulated in sporadic colon carcinomas, indicating that WISP1 might be an oncoprotein in colon cancer $[2,45]$. In vitro experiments have shown that indomethacin induces apoptosis and inhibited proliferation partly via downregulation of WISP1 in colon cancer cells [46]. In addition, overexpression of DHX32 increased the expression of WISP1, MMP-7 and VEGFA through activation of the Wnt pathway, resulting in colon cancer progression and metastasis [47]. Downregulation of WISP1 caused inhibition of cell growth and invasion, induction of apoptosis and cell cycle arrest at G1 phase in colon cancer cell lines [48]. In vivo experiments have shown that inhibition of WISP1 slows the progress of tumor formation. WISP1 expression has been shown to be substantially increased in colon cancer tissues and is associated with advanced pathological stage and poor prognosis [48]. This integrated analysis supports that WISP1 could be an oncogene in colon cancer. An aberrant level of WISP2 expression has been observed in colon cancer. Interestingly, WISP2 DNA expression has been shown to be amplified, but RNA expression is reduced in most colon tumors [2]. One group reported that WISP-3 is overexpressed in human colon tumors [2]. However, another group found that WISP3 harbors loss of expression, frameshifts, and mutations in colon cancer, suggesting that WISP3 could play a tumor suppressive role in colon cancer [49]. Due to limited studies on WISP2 and WISP3, it is necessary to determine the role of WISP2 and WISP3 in colon cancer development and progression.

\section{Gastric cancer}

The WISP family has been determined to be involved in gastric tumorigenesis. WISP1 expression levels have been shown to be upregulated in gastric cancer tissues. Inhibition of WISP1 leads to decreases in cell proliferation, migration and invasion in gastric cancer cells via suppression of cyclin D1 and EMT progression, demonstrating that WISP1 could be an oncogene in gastric cancer [50]. Emerging evidence has shown that WISP2 plays a critical role in the development of gastric cancer. Consistent with this role, the expression of WISP2 is associated with tumor stage, differentiation status, and overall survival [51]. The depletion of WISP2 has been shown to enhance cell growth, migration and invasion, whereas overexpression of WISP2 inhibits cell metastasis via regulating EMT and downregulating the expression and activity of MMP-9 and MMP-2 through JNK and ERK in gastric cancer cells [51]. This study suggested that WISP2 could be a potential tumor suppressor in gastric cancer. However, another study validated that WISP2 is highly expressed in gastric tissues compared to adjacent normal tissues [52]. It has been reported that WISP2 could regulate the $\mathrm{Wnt} / \beta$-catenin signaling pathway in gastric cancer cells. Moreover, WISP2 and $\beta$-catenin exhibit a positive correlation in gastric cancer patients, which was observed in patients with gastric cancer at early stages [52]. Thus, the expression of WISP2 and $\beta$-catenin could be a biomarker for the prediction and prognosis of gastric cancer patients.

WISP3 has been identified to exhibit mutations and loss of expression in gastric cancer, indicating the antitumor role of WISP3 in gastric cancer [49]. Consistently, the WISP3 gene is mutated by approximately $11-20 \%$ in microsatellite unstable gastric carcinoma [53]. Interestingly, high WISP3 high expression levels are closely associated with gastric cancer size and tumor invasion, indicating that WISP3 could be an oncoprotein in gastric cancer [54]. Consistent with this characteristic, the depletion of WISP3 has been shown to inhibit cell proliferation, migration and invasion via prevention of $\beta$-catenin transfer from the cytoplasm to the nucleus and subsequent suppression of $\mathrm{Wnt} / \beta$-catenin signaling and its downstream genes in gastric cancer [54]. This finding suggests that WISP3 could be a potential therapeutic target for gastric cancer.

\section{Pancreatic cancer}

Several groups have explored the role of the WISP family in the progression of pancreatic cancer. For instance, the down-regulation of BRCA2 has been shown to promote malignant transformation partly via increased WISP1 and decreased WISP2 expression in pancreatic cancer cells [55]. This study only indicates the potential role of WISP1 in pancreatic cancer. Interestingly, there is no direct evidence to show the physiological function 
of WISP1 in pancreatic cancer. WISP2 expression has been detected in normal and cancerous epithelial cells of the pancreas [56]. WISP2 mRNA expression was undetected in pancreatic cancer stromal cells [56]. Previous studies have suggested that WISP2 has a pathological role in the regulation of pancreatic cancers via regulating microenvironments. WISP2 expression is downregulated in pancreatic cancer tissues [57]. The WISP2 recombinant protein promotes mesenchymal-epithelial transition (MET) in pancreatic cancer cells. Moreover, loss of WISP2 expression has been observed in p53 mutant pancreatic cancer cell lines, indicating that p53 could regulate the expression of WISP2 in pancreatic cancer cells [57]. Notably, Wu et al. reported that protein phosphate 2A (PP2A) inhibitors inhibit cell growth and migration through suppression of the $\mathrm{Wnt} / \beta$-catenin pathway, including WISP2, in pancreatic cancer cells [58]. Because the function of WISP1 and WISP3 has not been determined in pancreatic cancer, it is recommended to investigate the biological function and molecular mechanism of the WISP family in pancreatic carcinogenesis and progression.

\section{Lung cancer}

The WISP family has been involved in the progression of lung cancer. It has been shown that WISP1 overexpression decreases cell motility and invasion via suppression of Rac activity in lung cancer cells [59]. Controversially, several reports have implied an oncogenic role of WISP1 in lung cancer. Matsubara et al. found that S100A4 upregulates WISP1 expression, which could be involved in lung cancer progression [60]. Similarly, WISP-1 was found to be upregulated in primary lung cancer tissues, which is correlated with tumor histology [61]. Interestingly, WISP1 has been reported to have a total of twenty-eight polymorphisms, which are correlated with the chemotherapeutic toxicity, hematologic toxicity and gastrointestinal toxicity in lung cancer. These genotypes of WISP1 may provide a potential for further clinical application of personalized diagnosis and platinum-based chemotherapy in lung cancer patients $[62,63]$. Additionally, overexpression of WISP1 has been shown to contribute to pulmonary metastases in D122 Lewis lung cancer mouse models [64]. WISP2 exhibits higher methylation levels in cisplatin (DDP)-resistant lung cancer tumors, which tend to be associated with adverse overall survival, implying that WISP2 may play a potential role in cisplatin resistance [65]. Furthermore, epigallocatechin-3-gallate (EGCG), which is the primary polyphenol in green tea, has been shown to reverse DDP resistance via demethylation of WISP2 in lung cancer cells [66]. Only one study identified the WISP3 mutation in early non-smoking lung cancer patients [67], indicating the involvement of WISP3 in lung cancer. In-depth investigations are required to address the detailed functions of the WISP family in lung cancer development and progression.

\section{Melanoma}

WISP1 has been reported to promote pulmonary metastases in melanoma cell lines, suggesting that WISP1 plays a pivotal oncogenic role in melanoma [64]. However, decreased expression of WISP1 has been detected in melanoma nests compared to the adjacent normal dermis [68]. Overexpression of Notch1 signaling in stromal fibroblasts has been shown to suppress cell growth via upregulation of WISP1 in melanoma [68]. Moreover, WISP1 has been shown to be aberrantly expressed in both melanoma cells and the tumor periphery by inhibiting their response to IL12 to exert paracrine action on immune cells [69]. Furthermore, another study demonstrated that the Notch1-WISP-1 axis governs stromal regulation of melanoma metastasis, indicating that this axis could be a potential target for the treatment of melanoma metastasis [70]. By fluorescence in situ hybridization technology, melanoma samples have shown decreases in copy numbers near or at WISP3 [71]. To date, studies regarding the role of WISP2 and WISP3 are not available; therefore, the function of WISP must be determined in the near future.

\section{Prostate cancer}

Prostate cancer is a leading cause of death in males. The WISP family is linked to prostate cancer progression. The level of WISP1 expression is upregulated in prostate cancer tissues, especially at early stages. Anti-WISP1 antibody treatment has led to the inhibition of prostate cancer cell growth [72]. Consistent with this result, osteoblast-derived WISP1 has been shown to promote migration and expression of VCAM-1 by downregulating miR-126 via $\alpha v \beta 1$ integrin, FAK, and p38 signaling pathways [73]. Recently, it has been reported that osteoblastsecreted WISP-1 enhances cell adhesion to bone through the VCAM-1/ $\alpha 4 \beta 1$ integrin pathway in prostate cancer cells [74].

\section{Oral carcinoma}

The WISP family has been identified to be associated with oral tumorigenesis. An in vitro experimental study has shown that knockdown of WISP1 induces apoptosis 
and inhibits the invasion in oral squamous cell carcinoma (OSCC) cells [75]. Increased WISP1 expression has been detected in tissues of OSCC patients and is correlated with poor survival and treatment failure in human OSCC [75]. WISP1 promotes cell migration and increases intercellular adhesion molecule-1 (ICAM-1) expression through the $\alpha v \beta 3$ integrin receptor and the ASK1, JNK/ $\mathrm{p} 38$, and activator protein 1 (AP-1) pathways in OSCC cells [76]. Clinically, WISP-1 expression has been associated with the tumor stage in OSCC patients [76]. This group further determined that WISP1 enhances angiogenesis by promoting VEGF-A expression. Consistently, WISP1 expression is associated with VEGF-A levels in OSCC specimens. Mechanistically, WISP-1 upregulates VEGF-A expression through the $\alpha v \beta 3$ integrin/FAK/cSrc pathway, and subsequently activates the EGFR/ERK/ HIF-1 $\alpha$ pathway in OSCC [77]. Moreover, high expression of WISP1 due to its hypomethylation has been observed in OSCC patients with lymph node metastasis. High WISP1 expression is correlated with lymph node (LN) metastasis and survival, implying that WISP1 could be a potential biomarker for predicting $\mathrm{LN}$ metastasis in OSCC [78]. Consistent with this observation, WISP1 increases the expression of VEGF-C via inhibition of miR-300 and regulation of the $\alpha v \beta 3$ integrin/integrinlinked kinase/Akt pathway in OSCC. Indeed, the correlation between WISP1 and VEGF-C in OSCC tissues has been identified [79]. Another study demonstrated that the WISP1 rs2929970 polymorphism is susceptible to OSCC in individuals who smoke, whereas WISP1 rs 16893344 is causally linked to the occurrence of OSCC in betel nut chewing individuals [80]. This finding indicates that the WISP1 polymorphism could be a marker or treatment target in OSCC. It has been illustrated that the amplification of WISP1 is associated with a significantly decreased survival in oropharyngeal squamous cell carcinomas (OPSCC) [81]. One report has revealed a higher level of WISP2 expression in salivary gland tumor-derived cell lines [82]. There are no available studies referring to the function of WISP3 in oral carcinoma. Therefore, it is warranted to clarify the role of WISP2 and WISP3 in oral carcinoma in the near future.

\section{Esophageal squamous cell carcinoma (ESCC)}

WISP-1 overexpression has been shown to enhance cell growth in ESCC cell lines and is closely correlated with tumor size, tumor type, lymph node metastasis and poor prognosis of ESCC [83], suggesting that
WISP1 could be a clinical biomarker for a poor prognosis in ESCC. Similarly, another group validated that WISP1 is highly expressed and associated with overall survival in ESCC patients [84]. WISP-1 overexpression has also been shown to be associated with radioresistance in esophageal cancer cells and mice during fractionated irradiation, while depletion of WISP1 reverses radioresistance and leads to cell death [85]. Zhang et al. observed that WISP1 is involved in radioresistance mainly via inhibiting irradiation-mediated DNA damage and activation of PI3K kinase. Radiation treatment leads to the upregulation of BOKAS lncRNA and subsequently increases WISP1 expression, resulting in radioresistance. This study provided insight regarding WISP1 regulation in response to radiation, showing a positive feedback loop that causes radioresistance [84]. Notably, WISP1 has been shown to be highly expressed in radioresistant cells with an EMT phenotype in ESCC, suggesting that inhibition of WISP1 could be an attractive approach to overcome EMT-associated radioresistance in ESCC [86]. These reports clearly suggest that WISP1 plays an oncogenic role in ESCC and could be a potential target for treating ESCC. To date, the role of WISP2 and WISP3 in ESCC remains unelucidated.

\section{Osteosarcoma and chondrosarcoma}

WISP1 has been identified as an osteogenic potentiating factor that enhances mesenchymal cell proliferation and induces osteoblastic differentiation, but suppresses chondrocytic differentiation, implying that WISP1 is a key molecule for bone development and fracture repair [87]. In support of these characteristics, WISP1 has a positive influence on bone cell differentiation and formation via enhancing BMP-2 activity [88, 89]. Due to the role of WISP1 in bone cell differentiation, dysregulated WISP1 could be involved in human osteosarcoma. In fact, two studies confirmed this role because WISP1 has been found to be highly expressed in osteosarcoma patients and is determined to be associated with tumor stage [90]. WISP1 promotes the migration of osteosarcoma cells through upregulation of MMP-2 and MMP-9 via several signaling pathways [90]. Recently, WISP-1 has been shown to increase VEGF-A expression and angiogenesis via regulation of the FAK/JNK/HIF- $1 \alpha$ pathway, and inhibition of miR-381 expression in osteosarcoma [91]. It is necessary to explore the role of WISP2 and WISP3 in osteosarcoma tumorigenesis because there are no available reports that define the function of WISP2/3 in osteosarcoma. 
WISP1 enhances cell migration by increasing MMP-2 expression by regulating the $\alpha 5 \beta 1$ integrin receptor, FAK, MEK, ERK, p65 and NF- $\mathrm{kB}$ signal transduction pathway in chondrosarcoma, suggesting that WISP1 may play an oncogenic role in chondrosarcoma [92]. Interestingly, two WISP1 variants (WISP1v and WISP1vx) have been identified in a human chondrosarcoma-derived chondrocytic cell line. Overexpression of WISP1v has been shown to enhance chondrocyte differentiation toward endochondral ossifications, while WISP1vx is involved in the transformed phenotypes of chondrosarcomas [93]. However, one study has shown that WISP1 expression is decreased in higher-grade chondrosarcomas [94], indicating that WISP1 function in chondrosarcoma is controversial and needs to be clarified. WISP3 promotes the migration of chondrosarcoma cells via upregulation of ICAM-1 expression by regulating multiple molecules, including $\alpha v \beta 3$ and $\alpha v \beta 5$ integrin receptors, FAK, MEK, ERK, c-Jun, and AP-1 [95]. In addition, WISP3 enhances VEGF-A production and induces angiogenesis by inhibiting miR-452, suggesting that WISP3 may be involved in cell differentiation and migration in chondrosarcoma [96].

\section{WISP in gynecological cancers and other tumors}

Increased expression of WISP-1 has been observed in endometrial endometrioid adenocarcinoma (EEC) compared to that in the secretory endometrium. Strikingly, high expression of WISP-1 is associated with poor survival in EEC [97]. A significant correlation between genetic polymorphisms of WISP1 and invasive cervical cancer has been observed. Genotype AA in WISP1 SNP rs2977537 enhances the risk of invasive cervical cancer, whereas genotypes AG/GG in rs2977530 decrease the susceptibility to invasive cervical cancer [98]. Zheng et al. used cDNA and tissue microarrays to analyze the gene expression profiles in epithelial ovarian tumors and found that WISP2 is a new candidate oncogene for epithelial ovarian cancer [99].

WISP2 is downregulated in leiomyoma tissues compared to the normal myometrial counterparts [100]. Moreover, overexpression of WISP2 inhibits cell proliferation and motility in human myometrial and leiomyoma smooth muscle cells [100]. Interestingly, WISP2 is induced by heparin in vascular smooth muscle cells, but not in uterine smooth muscle cells [100]. This data indicated that loss of WISP2 expression in normal myometrium could contribute to leiomyomas. One study showed that WISP2 is overexpressed in the gastrointestinal peptide (GIP)-dependent corticotropin/ACTH-independent macronodular adrenal hyperplasia (AIMAH), suggesting that WISP2 could play a role in adrenocortical hyperplasias and tumors [101]. Inhibition of WISP2 has been observed in clear-cell renal cell carcinoma (ccRCC), indicating that WISP2 could be a tumor suppressor in ccRCC.

\section{Conclusion and perspective}

In summary, WISP proteins are critically involved in various cellular progresses, including cell proliferation, apoptosis, invasion and metastasis in cancer cells. Moreover, WISP proteins play important roles through the regulation of their downstream targets in the development and progression of human cancers (Tables 1, 2, 3). Notably, WISP proteins could exhibit oncogenic or tumor suppressive functions in different tumor types. In this regard, targeting WISP proteins could be a novel approach for the treatment of human malignancies. It is necessary to design personalized medicine to target WISP proteins in specific tissues. Specifically, WISP inhibitors need to be developed for cancer patients with increased expression of the WISP oncoprotein. One alternative strategy is to regulate upstream effectors that control the expression of WISP proteins. We postulate that targeting WISP proteins for cancer therapy is intriguing.

The functions of WISP proteins have been revealed; however, several critical questions need to be addressed. For example, what are the WISP binding partners? Which receptors and signaling pathways are regulated by WISP? What are the direct targets of WISP? How does WISP govern their downstream targets? To address these concerns, using tissue-specific knockout mouse models or transgenic mice are advantageous approaches that could be used to understand the contribution of WISP proteins in carcinogenesis. In addition, the detection of pathological gene alterations of WISP in cancer patients is required. High-throughput sequencing technology could be helpful in determining the molecular mechanism of WISP-involved tumorigenesis. These in-depth studies could provide 
Table 1 Role of WISP1 in human cancers

\begin{tabular}{|c|c|c|c|}
\hline Cancer type & Function & Target & Reference \\
\hline Breast cancer & $\begin{array}{l}\text { Increases cell proliferation, migration } \\
\text { and invasion; promotes tumor growth; } \\
\text { induces EMT; promotes type } 2 \text { cell- } \\
\text { mediated immunity; inhibits type } 1 \text { cell } \\
\text { mediated immunity; suppresses tumor } \\
\text { metastasis }\end{array}$ & $\begin{array}{l}\text { Inhibits E-cadherin, NDRG1; increases } \\
\text { N-cadherin, Snail, and } \beta \text {-catenin }\end{array}$ & {$[4,6-10,102]$} \\
\hline Hepatocellular carcinoma (HCC) & $\begin{array}{l}\text { Promotes cell growth; Inhibits WISP1; sup- } \\
\text { presses cell proliferation, migration, and } \\
\text { adhesion; associated with invasion, pTNM } \\
\text { stage, and patient survival }\end{array}$ & $\begin{array}{l}\text { Induced by Wnt/ } \beta \text {-catenin pathway; acti- } \\
\text { vates pAkt, GSK-3 } \beta \text {, and MMP-2 }\end{array}$ & {$[35-38]$} \\
\hline Colon cancer & $\begin{array}{l}\text { Promotes tumorigenesis, progression and } \\
\text { metastasis; associated with advanced } \\
\text { pathological stage and poor prognosis; } \\
\text { harbors loss of expression, frameshifts and } \\
\text { mutations }\end{array}$ & Induced by DHX32, Wnt pathway & {$[2,45-48]$} \\
\hline Gastric cancer & $\begin{array}{l}\text { Promotes cell proliferation, migration and } \\
\text { invasion }\end{array}$ & Activates cyclin D1 & {$[50]$} \\
\hline Pancreatic cancer & Promotes malignant transformation & Inhibited by BRCA2 & {$[55]$} \\
\hline Lung cancer & $\begin{array}{l}\text { Retards cell motility and invasion; promotes } \\
\text { cancer progression; correlated to tumor } \\
\text { histology; correlated to chemotherapeu- } \\
\text { tic toxicity; leads to pulmonary metas- } \\
\text { tases }\end{array}$ & Increased by S100A4 & {$[59-64]$} \\
\hline Melanoma & $\begin{array}{l}\text { Promotes pulmonary metastases; sup- } \\
\text { presses cell growth }\end{array}$ & Increased by Notch1 & {$[64,68-70]$} \\
\hline Prostate cancer & $\begin{array}{l}\text { Promotes cancer progression, migration, } \\
\text { growth; associated with cancer stage; } \\
\text { enhances cell adherence to bone }\end{array}$ & Increases VCAM-1; inhibits miR-126 & {$[72-74]$} \\
\hline Oral carcinoma & $\begin{array}{l}\text { Promotes cell migration; correlated with the } \\
\text { tumor stage and poor survival; enhances } \\
\text { angiogenesis }\end{array}$ & $\begin{array}{c}\text { Enhances ICAM-1, VEGF-A and VEGF-C; acti- } \\
\text { vates integrin avß33/FAK/c-Src and EGFR/ } \\
\text { ERK/HIF-1 a pathways; inhibits miR-300 }\end{array}$ & {$[75-81]$} \\
\hline Esophageal squamous cell carcinoma & $\begin{array}{l}\text { Enhances cell growth; associated with } \\
\text { tumor size, tumor type, lymph node } \\
\text { metastasis and poor prognosis; contrib- } \\
\text { utes to radioresistance }\end{array}$ & Not detecte & {$[83-86]$} \\
\hline Osteosarcoma & $\begin{array}{l}\text { Enhances bone cell differentiation and } \\
\text { formation; associated with tumor stage; } \\
\text { promotes cancer cell migration and tube } \\
\text { formation }\end{array}$ & $\begin{array}{l}\text { Enhances BMP-2, MMP-2 and MMP-9; } \\
\text { improves VEGF-A; inhibits miR-381 }\end{array}$ & {$[87-91]$} \\
\hline Chondrosarcoma & Promotes cell migration & Upregulates MMP-2 & {$[92-94]$} \\
\hline Endometrial endometrioid adenocarcinoma & $\begin{array}{l}\text { Associated with poor survival and clinical } \\
\text { grades }\end{array}$ & Not detected & {$[97]$} \\
\hline
\end{tabular}


Table 2 Role of WISP2 in human cancers

\begin{tabular}{|c|c|c|c|}
\hline Cancer type & Function & Target & Reference \\
\hline Breast cancer & $\begin{array}{l}\text { Exhibits estrogen and progesterone inducible expres- } \\
\text { sion; enhances tumor cell proliferation and growth; } \\
\text { associated with metastasis and late stage; inhibits } \\
\text { tumor growth, migration and invasion; causes cell } \\
\text { cycle arrest at the G1/G1 phase }\end{array}$ & $\begin{array}{l}\text { Induced by PKA; inhibits Snail, E-cadherin, MMP-2, } \\
\text { MMP-9, Skp2, PI3K Akt, TGF- } \beta \text { pathways; inhibited } \\
\text { by p53 mutants; induces PD-L1, p27, and FOXO3a }\end{array}$ & $\begin{array}{l}{[9,11-15} \\
\quad 18-21 \\
103,104]\end{array}$ \\
\hline Hepatocellular carcinoma & $\begin{array}{l}\text { Promotes cell growth, proliferation and migration; } \\
\text { involved in HCC progression }\end{array}$ & $\begin{array}{l}\text { Increased by } \beta \text {-catenin, and TCF-4J; inhibited by } \\
\text { GSK3 } \beta\end{array}$ & {$[39-44]$} \\
\hline Colon cancer & $\begin{array}{l}\text { WISP2 DNA expression is amplified, but function } \\
\text { remains unknown }\end{array}$ & Not detected & {$[2]$} \\
\hline Gastric cancer & $\begin{array}{l}\text { Associated with tumor stage, differentiation status, } \\
\text { and survival; inhibits cell growth, migration and } \\
\text { invasion }\end{array}$ & $\begin{array}{l}\text { Downregulates MMP-9 and MMP-2 through JNK and } \\
\text { ERK pathways }\end{array}$ & {$[51,52]$} \\
\hline Pancreatic cancer & $\begin{array}{l}\text { Promotes mesenchymal-epithelial transition; regu- } \\
\text { lates pancreatic cancers via regulating microenvi- } \\
\text { ronments }\end{array}$ & Promoted by BRCA2 & {$[55-58]$} \\
\hline Lung cancer & Associated with adverse overall survival & $\mathrm{N} / \mathrm{A}$ & {$[65,66]$} \\
\hline Leiomyoma & inhibits cell proliferation and motility & $\mathrm{N} / \mathrm{A}$ & {$[100]$} \\
\hline
\end{tabular}

Table 3 Role of WISP3 in human cancers

\begin{tabular}{|c|c|c|c|}
\hline Cancer type & Function & Target & Reference \\
\hline Breast cancer & $\begin{array}{l}\text { Suppresses cell growth, invasion, metastasis; maintains } \\
\text { acinar organization; reverses EMT to MET, reduces TICs } \\
\text { (tumor initiating cells) }\end{array}$ & $\begin{array}{l}\text { Inhibits IGF-IR, IRS1 and ERK-1/2, snail and ZEB1, BMP4, } \\
\text { TAK1 and p38 kinase, PI3KVAkt, TßRIII, and Notch1; } \\
\text { increases E-cadherin }\end{array}$ & {$[22-34]$} \\
\hline $\begin{array}{l}\text { Hepatocellular } \\
\text { carcinoma } \\
(\mathrm{HCC})\end{array}$ & $\begin{array}{l}\text { Detected in only a few HCC samples, and its function } \\
\text { remains unknown }\end{array}$ & Not detected & {$[37]$} \\
\hline Colon cancer & Harbors loss of expression, frameshifts, and mutations & Not detected & {$[2,49]$} \\
\hline Gastric cancer & $\begin{array}{l}\text { Exhibits mutations and loss of expression; associated with } \\
\text { cancer size and tumor invasion; promotes cell prolifera- } \\
\text { tion, migration and invasion }\end{array}$ & Induces Wnt/ $\beta$-catenin signaling & {$[49,53,54]$} \\
\hline Lung cancer & $\begin{array}{l}\text { Exhibits mutations in early nonsmoking lung cancer } \\
\text { patients }\end{array}$ & Not detected & {$[67]$} \\
\hline Melanoma & Shows loss of copy numbers & & {$[71]$} \\
\hline Chondrosarcoma & Promotes cell migration and differentiation & Upregulates ICAM-1and VEGF-A; inhibits miR-452 & {$[95,96]$} \\
\hline
\end{tabular}

experimental evidence and a rationale for developing inhibitors of WISP proteins for cancer treatments.

\section{Abbreviations}

WISP: WNT1 inducible signaling pathway protein; CNN: connective tissue growth factor/cysteine-rich 61/nephroblastoma overexpressed; CYR61: cysteine-rich 61/CCN1; CTGF: connective tissue growth factor/CCN2; NOV: nephroblastoma overexpressed/CCN3; VWC: von Willebrand factor-like motif; TSP-1: thrombospondin type 1; CT: carboxy-terminal; EMT: epithelial-mesenchymal transition; PKA: protein kinase A; MMP: matrix metalloproteinase; ALDH: aldehyde dehydrogenase; IBC: inflammatory breast cancer; PI3K: phosphatidylinositol 3-kinase; BMP4: bone morphogenetic proteins; TßRIII: type III TGF- $\beta$ receptor; TICs: tumor initiating cells; HCC: hepatocellular carcinoma;

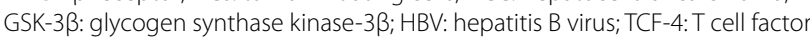
4; MET: Mesenchymal-epithelial transition; PP2A: protein phosphate 2A; EGCG: epigallocatechin-3-gallate; OSCC: oral squamous cell carcinoma; ICAM-1: intercellular adhesion molecular-1; AP-1: activator protein 1; OPSCC: oropharyngeal squamous cell carcinomas; ESCC: esophageal squamous cell carcinoma; EEC: endometrial endometrioid adenocarcinoma; GIP: gastrointestinal peptide;
AIMAH: corticotropin/ACTH-independent macronodular adrenal hyperplasis; cCRCC: clear-cell renal cell carcinoma.

\section{Authors' contributions}

YL and YS searched literature regarding to WISP1 and WISP2. MY and XH searched literature regarding to WISP3, and made the figures and tables. YL, YS, ZW, and XZ wrote the manuscript. All authors read and approved the final manuscript.

\section{Author details}

${ }^{1}$ Department of Obstetrics and Gynecology, The Second Affiliated Hospital of Wenzhou Medical University, No. 109 Xueyuan Xi Road, Wenzhou 325027, Zhejiang, China. ${ }^{2}$ Center of Scientific Research, The Second Affiliated Hospital of Wenzhou Medical University, Wenzhou 325027, Zhejiang, China. ${ }^{3}$ Department of Biochemistry and Molecular Biology, School of Laboratory Medicine Bengbu Medical College, Bengbu 233030, Anhui, China. ${ }^{4}$ Department of Pathology, Beth Israel Deaconess Medical Center, Harvard Medical School, 330 Brookline Ave, Boston, MA 02215, USA.

\section{Acknowledgements}

Not applicable. 


\section{Competing interests}

The authors declare that they have no competing interests.

\section{Availability of data and materials}

Not applicable.

\section{Consent for publication}

Not applicable.

Ethics approval and consent to participate

Not applicable.

\section{Funding}

This work was supported by grants from National Natural Science Foundation of China (NSFC numbers 81572936 and 81773186) and supported by Major Science and Technology Planning Project of Wenzhou city (No. ZS2017006).

\section{Publisher's Note}

Springer Nature remains neutral with regard to jurisdictional claims in published maps and institutional affiliations.

Received: 3 August 2018 Accepted: 2 January 2019

Published online: 16 January 2019

\section{References}

1. Brigstock DR. The CCN family: a new stimulus package. J Endocrinol. 2003;178:169-75

2. Pennica D, Swanson TA, Welsh JW, Roy MA, Lawrence DA, Lee J, et al. WISP genes are members of the connective tissue growth factor family that are up-regulated in wnt-1-transformed cells and aberrantly expressed in human colon tumors. Proc Natl Acad Sci USA. 1998;95:14717-22.

3. Kleer CG. Dual roles of CCN proteins in breast cancer progression. J Cell Commun Signal. 2016;10:217-22.

4. Saxena N, Banerjee S, Sengupta K, Zoubine MN, Banerjee SK. Differential expression of WISP-1 and WISP-2 genes in normal and transformed human breast cell lines. Mol Cell Biochem. 2001;228:99-104.

5. Xie D, Nakachi K, Wang H, Elashoff R, Koeffler HP. Elevated levels of connective tissue growth factor, WISP-1, and CYR61 in primary breast cancers associated with more advanced features. Can Res. 2001;61:8917-23.

6. Chiang KC, Yeh CN, Chung LC, Feng TH, Sun CC, Chen MF, et al. WNT-1 inducible signaling pathway protein-1 enhances growth and tumorigenesis in human breast cancer. Sci Rep. 2015;5:8686.

7. Klinke DJ 2 nd. Induction of Wnt-inducible signaling protein-1 correlates with invasive breast cancer oncogenesis and reduced type 1 cellmediated cytotoxic immunity: a retrospective study. PLoS Comput Biol. 2014;10:e1003409.

8. Chiang KC, Hsu SY, Lin SJ, Yeh CN, Pang JH, Wang SY, et al. PTEN insufficiency increases breast cancer cell metastasis in vitro and in vivo in a xenograft zebrafish model. Anticancer Res. 2016;36:3997-4005.

9. Davies SR, Watkins G, Mansel RE, Jiang WG. Differential expression and prognostic implications of the CCN family members WISP-1, WISP-2, and WISP-3 in human breast cancer. Ann Surg Oncol. 2007;14:1909-18.

10. Taghavi A, Akbari ME, Hashemi-Bahremani M, Nafissi N, Khalilnezhad A, Poorhosseini SM, et al. Gene expression profiling of the 8q22-24 position in human breast cancer: TSPYL5, MTDH, ATAD2 and CCNE2 genes are implicated in oncogenesis, while WISP1 and EXT1 genes may predict a risk of metastasis. Oncol Lett. 2016;12:3845-55.

11. Inadera H, Hashimoto S, Dong HY, Suzuki T, Nagai S, Yamashita T, et al. WISP-2 as a novel estrogen-responsive gene in human breast cancer cells. Biochem Biophys Res Commun. 2000;275:108-14.

12. Inadera H, Dong HY, Matsushima K. WISP-2 is a secreted protein and can be a marker of estrogen exposure in MCF-7 cells. Biochem Biophys Res Commun. 2002;294:602-8.

13. Banerjee S, Saxena N, Sengupta K, Tawfik O, Mayo MS, Banerjee SK. WISP-2 gene in human breast cancer: estrogen and progesterone inducible expression and regulation of tumor cell proliferation. Neoplasia. 2003;5:63-73.

14. Inadera H. Estrogen-induced genes, WISP-2 and pS2, respond divergently to protein kinase pathway. Biochem Biophys Res Commun. 2003:309:272-8.

15. Zoubine MN, Banerjee S, Saxena NK, Campbell DR, Banerjee SK. WISP-2: a serum-inducible gene differentially expressed in human normal breast epithelial cells and in MCF-7 breast tumor cells. Biochem Biophys Res Commun. 2001;282:421-5.

16. Banerjee S, Dhar G, Haque I, Kambhampati S, Mehta S, Sengupta K, et al. CCN5/WISP-2 expression in breast adenocarcinoma is associated with less frequent progression of the disease and suppresses the invasive phenotypes of tumor cells. Can Res. 2008;68:7606-12.

17. Dhar G, Banerjee S, Dhar K, Tawfik O, Mayo MS, Vanveldhuizen PJ, et al. Gain of oncogenic function of p53 mutants induces invasive phenotypes in human breast cancer cells by silencing CCN5/WISP-2. Can Res. 2008;68:4580-7.

18. Noman MZ, Janji B, Abdou A, Hasmim M, Terry S, Tan TZ, et al. The immune checkpoint ligand PD-L1 is upregulated in EMT-activated human breast cancer cells by a mechanism involving ZEB-1 and miR200. Oncoimmunology. 2017;6:e1263412.

19. Haque I, Banerjee S, De A, Maity G, Sarkar S, Majumdar M, et al. CCN5/ WISP-2 promotes growth arrest of triple-negative breast cancer cells through accumulation and trafficking of p27(Kip1) via Skp2 and FOXO3a regulation. Oncogene. 2015;34:3152-63.

20. Fritah A, Saucier C, De Wever O, Bracke M, Bieche I, Lidereau R, et al. Role of WISP-2/CCN5 in the maintenance of a differentiated and noninvasive phenotype in human breast cancer cells. Mol Cell Biol. 2008:28:1114-23.

21. Ferrand N, Gnanapragasam A, Dorothee G, Redeuilh G, Larsen AK, Sabbah M. Loss of WISP2/CCN5 in estrogen-dependent MCF7 human breast cancer cells promotes a stem-like cell phenotype. PLoS ONE. 2014:9:e87878

22. van Golen KL, Davies S, Wu ZF, Wang Y, Bucana CD, Root H, et al. A novel putative low-affinity insulin-like growth factor-binding protein, LIBC (lost in inflammatory breast cancer), and RhoC GTPase correlate with the inflammatory breast cancer phenotype. Clin Cancer Res. 1999:5:2511-9.

23. Kleer CG, Zhang Y, Pan Q, van Golen KL, Wu ZF, Livant D, et al. WISP3 is a novel tumor suppressor gene of inflammatory breast cancer. Oncogene. 2002;21:3172-80.

24. Kleer CG, Zhang Y, Pan Q, Gallagher G, Wu M, Wu ZF, et al. WISP3 and RhoC guanosine triphosphatase cooperate in the development of inflammatory breast cancer. Breast Cancer Res BCR. 2004;6:R110-5.

25. Huang W, Zhang Y, Varambally S, Chinnaiyan AM, Banerjee M, Merajver $\mathrm{SD}$, et al. Inhibition of CCN6 (Wnt-1-induced signaling protein 3) downregulates $\mathrm{E}$-cadherin in the breast epithelium through induction of snail and ZEB1. Am J Pathol. 2008;172:893-904.

26. Zhang Y, Pan Q, Zhong H, Merajver SD, Kleer CG. Inhibition of CCN6 (WISP3) expression promotes neoplastic progression and enhances the effects of insulin-like growth factor-1 on breast epithelial cells. Breast Cancer Res BCR. 2005;7:R1080-9.

27. Hayes MJ, Thomas D, Emmons A, Giordano TJ, Kleer CG. Genetic changes of Wnt pathway genes are common events in metaplastic carcinomas of the breast. Clin Cancer Res. 2008;14:4038-44.

28. Huang W, Gonzalez ME, Toy KA, Banerjee M, Kleer CG. Blockade of CCN6 (WISP3) activates growth factor-independent survival and resistance to anoikis in human mammary epithelial cells. Cancer Res. 2010;70:3340-50.

29. Kleer CG, Zhang Y, Pan Q, Merajver SD. WISP3 (CCN6) is a secreted tumor-suppressor protein that modulates IGF signaling in inflammatory breast cancer. Neoplasia. 2004;6:179-85.

30. Lorenzatti G, Huang W, Pal A, Cabanillas AM, Kleer CG. CCN6 (WISP3) decreases ZEB1-mediated EMT and invasion by attenuation of IGF-1 receptor signaling in breast cancer. J Cell Sci. 2011;124:1752-8.

31. Pal A, Huang W, Li X, Toy KA, Nikolovska-Coleska Z, Kleer CG. CCN6 modulates BMP signaling via the Smad-independent TAK1/p38 pathway, acting to suppress metastasis of breast cancer. Cancer Res. 2012;72:4818-28 
32. Pal A, Huang W, Toy KA, Kleer CG. CCN6 knockdown disrupts acinar organization of breast cells in three-dimensional cultures through upregulation of type III TGF-beta receptor. Neoplasia. 2012;14:1067-74.

33. Huang W, Martin EE, Burman B, Gonzalez ME, Kleer CG. The matricellular protein CCN6 (WISP3) decreases Notch1 and suppresses breast cancer initiating cells. Oncotarget. 2016;7:25180-93.

34. Martin EE, Huang W, Anwar T, Arellano-Garcia C, Burman B, Guan JL, et al. MMTV-cre;Ccn6 knockout mice develop tumors recapitulating human metaplastic breast carcinomas. Oncogene. 2017;36:2275-85

35. Cervello M, Giannitrapani L, Labbozzetta M, Notarbartolo M, D'Alessandro N, Lampiasi N, et al. Expression of WISPs and of their novel alternative variants in human hepatocellular carcinoma cells. Ann NY Acad Sci. 2004;1028:432-9.

36. Calvisi DF, Conner EA, Ladu S, Lemmer ER, Factor VM, Thorgeirsson SS. Activation of the canonical Wnt/beta-catenin pathway confers growth advantages in c-Myc/E2F1 transgenic mouse model of liver cancer. J Hepatol. 2005;42:842-9.

37. Ge J, Zhang XH, Wang F, Wang Y, Li QY, Tao W, et al. Effect of siRNA on Wisp-1 gene expression, proliferation, migration and adhesion of mouse hepatocellular carcinoma cells. Asian Pac J Trop Med. 2015;8:821-8

38. Zhang $H$, Li W, Huang $P$, Lin L, Ye H, Lin D, et al. Expression of CCN family members correlates with the clinical features of hepatocellular carcinoma. Oncol Rep. 2015;33:1481-92.

39. Fukutomi T, Zhou Y, Kawai S, Eguchi H, Wands JR, Li J. Hepatitis C virus core protein stimulates hepatocyte growth: correlation with upregulation of wnt-1 expression. Hepatology. 2005:41:1096-105.

40. Liu J, Ding X, Tang J, Cao Y, Hu P, Zhou F, et al. Enhancement of canonical Wnt/beta-catenin signaling activity by HCV core protein promotes cell growth of hepatocellular carcinoma cells. PLOS ONE. 2011;6:e27496.

41. Chen Z, Tang J, Cai X, Huang Y, Gao Q, Liang L, et al. HBx mutations promote hepatoma cell migration through the Wnt/beta-catenin signaling pathway. Cancer Sci. 2016;107:1380-9.

42. Anastas JN, Moon RT. WNT signalling pathways as therapeutic targets in cancer. Nat Rev Cancer. 2013;13:11-26.

43. Kahn M. Can we safely target the WNT pathway? Nat Rev Drug Discov. 2014;13:513-32.

44. Tomimaru Y, Koga H, Yano H, de la Monte S, Wands JR, Kim M. Upregulation of T-cell factor- 4 isoform-responsive target genes in hepatocellular carcinoma. Liver Int. 2013;33:1100-12.

45. Fischer H, Salahshor S, Stenling R, Bjork J, Lindmark G, Iselius L, et al. COL11A1 in FAP polyps and in sporadic colorectal tumors. BMC Cancer. 2001;1:17.

46. Wang J, Zhang GY, Li XH. Effect of indomethacin on Bfl-1, WISP-1 and proliferating cell nuclear antigen in colon cancer cell line HCT116 cells. Chin J Dig Dis. 2006;7:219-24.

47. Lin H, Liu W, Fang Z, Liang X, Li J, Bai Y, et al. Overexpression of DHX32 contributes to the growth and metastasis of colorectal cancer. Sci Rep. 2015:5:9247.

48. Wu J, Long Z, Cai H, Du C, Liu X, Yu S, et al. High expression of WISP1 in colon cancer is associated with apoptosis, invasion and poor prognosis. Oncotarget. 2016;7:49834-47.

49. Lee JH, Choi YJ, Je EM, Kim HS, Yoo NJ, Lee SH. Frameshift mutation of WISP3 gene and its regional heterogeneity in gastric and colorectal cancers. Hum Pathol. 2016;50:146-52.

50. Jia S, Qu T, Feng M, Ji K, Li Z, Jiang W, et al. Association of Wnt1-inducible signaling pathway protein-1 with the proliferation, migration and invasion in gastric cancer cells. Tumour Biol. 2017:39:1010428317699755.

51. Ji J, Jia S, Jia Y, Ji K, Hargest R, Jiang WG. WISP-2 in human gastric cancer and its potential metastatic suppressor role in gastric cancer cells mediated by JNK and PLC-gamma pathways. Br J Cancer. 2015;113:921-33.

52. Li L, Cui Y, Ji JF, Jiang WG. Clinical Correlation Between WISP2 and betaCatenin in Gastric Cancer. Anticancer Res. 2017:37:4469-73.

53. Tanaka S, Sugimachi K, Maehara S, Shimada M, Maehara Y. A loss of function mutation in WISP3 derived from microsatellite unstable gastric carcinoma. Gastroenterology. 2003;125:1563-4

54. Fang F, Zhao WY, Li RK, Yang XM, Li J, Ao JP, et al. Silencing of WISP3 suppresses gastric cancer cell proliferation and metastasis and inhibits Wnt/beta-catenin signaling. Int J Clin Exp Pathol. 2014;7:6447-61.
55. Wang Q, Liu H, Liu T, Shu S, Jiang H, Cheng S, et al. BRCA2 dysfunction promotes malignant transformation of pancreatic intraepithelial neoplasia. Anticancer Agents Med Chem. 2013;13:261-9.

56. Ghosh P, Banerjee S, Maity G, De A, Banerjee SK. Detection of CCN1 and CCN5 mRNA in human cancer samples using a modified in situ hybridization technique. Methods Mol Biol. 2017;1489:495-504.

57. Dhar G, Mehta S, Banerjee S, Gardner A, McCarty BM, Mathur SC, et al. Loss of WISP-2/CCN5 signaling in human pancreatic cancer: a potential mechanism for epithelial-mesenchymal-transition. Cancer Lett. 2007;254:63-70

58. Wu MY, Xie X, Xu ZK, Xie L, Chen Z, Shou LM, et al. PP2A inhibitors suppress migration and growth of PANC-1 pancreatic cancer cells through inhibition on the Wnt/beta-catenin pathway by phosphorylation and degradation of beta-catenin. Oncol Rep. 2014;32:513-22.

59. Soon LL, Yie TA, Shvarts A, Levine AJ, Su F, Tchou-Wong KM. Overexpression of WISP-1 down-regulated motility and invasion of lung cancer cells through inhibition of Rac activation. J Biol Chem. 2003;278:11465-70.

60. Matsubara D, Niki T, Ishikawa S, Goto A, Ohara E, Yokomizo T, et al. Differential expression of S100A2 and S100A4 in lung adenocarcinomas: clinicopathological significance, relationship to p53 and identification of their target genes. Cancer Sci. 2005;96:844-57.

61. Chen PP, Li WJ, Wang Y, Zhao S, Li DY, Feng LY, et al. Expression of Cyr61, CTGF, and WISP-1 correlates with clinical features of lung cancer. PLOS ONE. 2007:2:e534

62. Chen J, Yin J, Li X, Wang Y, Zheng Y, Qian C, et al. WISP1 polymorphisms contribute to platinum-based chemotherapy toxicity in lung cancer patients. Int J Mol Sci. 2014;15:21011-27.

63. Chen J, Yin JY, Li XP, Wang Y, Zheng Y, Qian CY, et al. Association of Wnt-inducible signaling pathway protein 1 genetic polymorphisms with lung cancer susceptibility and platinum-based chemotherapy response. Clin Lung Cancer. 2015;16(298-304):e1-2.

64. Margalit O, Eisenbach L, Amariglio N, Kaminski N, Harmelin A, Pfeffer R, et al. Overexpression of a set of genes, including WISP-1, common to pulmonary metastases of both mouse D122 Lewis lung carcinoma and B16-F10.9 melanoma cell lines. Br J Cancer. 2003;89:314-9.

65. Zhang YW, Zheng Y, Wang JZ, Lu XX, Wang Z, Chen LB, et al. Integrated analysis of DNA methylation and mRNA expression profiling reveals candidate genes associated with cisplatin resistance in non-small cell lung cancer. Epigenetics. 2014;9:896-909.

66. Zhang Y, Wang X, Han L, Zhou Y, Sun S. Green tea polyphenol EGCG reverse cisplatin resistance of A549/DDP cell line through candidate genes demethylation. Biomed Pharmacother. 2015;69:285-90.

67. Renieri A, Mencarelli MA, Cetta F, Baldassarri M, Mari F, Furini S, et al. Oligogenic germline mutations identified in early non-smokers lung adenocarcinoma patients. Lung Cancer. 2014;85:168-74.

68. Shao H, Cai L, Grichnik JM, Livingstone AS, Velazquez OC, Liu ZJ. Activation of Notch1 signaling in stromal fibroblasts inhibits melanoma growth by upregulating WISP-1. Oncogene. 2011;30:4316-26.

69. Kulkarni YM, Chambers E, McGray AJ, Ware JS, Bramson JL, Klinke DJ 2nd. A quantitative systems approach to identify paracrine mechanisms that locally suppress immune response to Interleukin-12 in the B16 melanoma model. Integr Biol (Camb). 2012;4:925-36.

70. Shao H, Cai L, Moller M, Issac B, Zhang L, Owyong M, et al. Notch1WISP-1 axis determines the regulatory role of mesenchymal stem cell-derived stromal fibroblasts in melanoma metastasis. Oncotarget. 2016;7:79262-73.

71. Moore SR, Persons DL, Sosman JA, Bobadilla D, Bedell V, Smith DD, et al. Detection of copy number alterations in metastatic melanoma by a DNA fluorescence in situ hybridization probe panel and array comparative genomic hybridization: a southwest oncology group study (S9431) Clin Cancer Res. 2008;14:2927-35.

72. Ono M, Inkson CA, Sonn R, Kilts TM, de Castro LF, Maeda A, et al. WISP1/ CCN4: a potential target for inhibiting prostate cancer growth and spread to bone. PLoS ONE. 2013;8:e71709.

73. Tai HC, Chang AC, Yu HJ, Huang CY, Tsai YC, Lai YW, et al. Osteoblastderived WNT-induced secreted protein 1 increases VCAM-1 expression and enhances prostate cancer metastasis by down-regulating miR-126. Oncotarget. 2014;5:7589-98.

74. Chang AC, Chen PC, Lin YF, Su CM, Liu JF, Lin TH, et al. Osteoblastsecreted WISP-1 promotes adherence of prostate cancer cells to 
bone via the VCAM-1/integrin alpha4beta1 system. Cancer Lett. 2018:426:47-56

75. Jung EK, Kim SA, Yoon TM, Lee KH, Kim HK, Lee DH, et al. WNT1-inducible signaling pathway protein-1 contributes to tumor progression and treatment failure in oral squamous cell carcinoma. Oncol Lett. 2017;14:1719-24.

76. Chuang JY, Chang AC, Chiang IP, Tsai MH, Tang CH. Apoptosis signalregulating kinase 1 is involved in WISP-1-promoted cell motility in human oral squamous cell carcinoma cells. PLoS ONE. 2013:8:e78022.

77. Chuang JY, Chen PC, Tsao CW, Chang AC, Lein MY, Lin CC, et al. WISP-1 a novel angiogenic regulator of the CCN family promotes oral squamous cell carcinoma angiogenesis through VEGF-A expression. Oncotarget. 2015;6:4239-52.

78. Clausen MJ, Melchers LJ, Mastik MF, Slagter-Menkema L, Groen HJ, van der Laan BF, et al. Identification and validation of WISP1 as an epigenetic regulator of metastasis in oral squamous cell carcinoma. Genes Chromosom Cancer. 2016;55:45-59.

79. Lin CC, Chen PC, Lein MY, Tsao CW, Huang CC, Wang SW, et al. WISP-1 promotes VEGF-C-dependent lymphangiogenesis by inhibiting miR-300 in human oral squamous cell carcinoma cells. Oncotarget. 2016;7:9993-10005.

80. Lau HK, Wu ER, Chen MK, Hsieh MJ, Yang SF, Wang LY, et al. Effect of genetic variation in microRNA binding site in WNT1-inducible signaling pathway protein 1 gene on oral squamous cell carcinoma susceptibility. PLoS ONE. 2017;12:e0176246.

81. van Kempen PM, Noorlag R, Braunius WW, Moelans CB, Rifi W, Savola S, et al. Clinical relevance of copy number profiling in oral and oropharyngeal squamous cell carcinoma. Cancer Med. 2015;4:1525-35.

82. Kouzu Y, Uzawa K, Kato M, Higo M, Nimura Y, Harada K, et al. WISP-2 expression in human salivary gland tumors. Int J Mol Med. 2006:17:567-73.

83. Nagai Y, Watanabe M, Ishikawa S, Karashima R, Kurashige J, Iwagami S, et al. Clinical significance of Wnt-induced secreted protein-1 (WISP-1/ CCN4) in esophageal squamous cell carcinoma. Anticancer Res. 2011:31:991-7.

84. Zhang H, Luo H, Hu Z, Peng J, Jiang Z, Song T, et al. Targeting WISP1 to sensitize esophageal squamous cell carcinoma to irradiation. Oncotarget. 2015;6:6218-34.

85. Li WF, Zhang L, Li HY, Zheng SS, Zhao L. WISP-1 contributes to fractionated irradiation-induced radioresistance in esophageal carcinoma cell lines and mice. PLoS ONE. 2014;9:e94751.

86. Zhang H, Luo H, Jiang Z, Yue J, Hou Q, Xie R, et al. Fractionated irradiation-induced EMT-like phenotype conferred radioresistance in esophageal squamous cell carcinoma. J Radiat Res. 2016;57:370-80.

87. French DM, Kaul RJ, D'Souza AL, Crowley CW, Bao M, Frantz GD, et al. WISP-1 is an osteoblastic regulator expressed during skeletal development and fracture repair. Am J Pathol. 2004;165:855-67.

88. Ono M, Inkson CA, Kilts TM, Young MF. WISP-1/CCN4 regulates osteogenesis by enhancing BMP-2 activity. J Bone Miner Res. 2011;26:193-208.

89. Kohara H, Tabata Y. Enhancement of ectopic osteoid formation following the dual release of bone morphogenetic protein 2 and Wnt1 inducible signaling pathway protein 1 from gelatin sponges. Biomaterials. 2011;32:5726-32.

90. Wu CL, Tsai HC, Chen ZW, Wu CM, Li TM, Fong YC, et al. Ras activation mediates WISP-1-induced increases in cell motility and matrix metalloproteinase expression in human osteosarcoma. Cell Signal. 2013;25:2812-22.

91. Tsai HC, Tzeng HE, Huang CY, Huang YL, Tsai CH, Wang SW, et al. WISP-1 positively regulates angiogenesis by controlling VEGF-A expression in human osteosarcoma. Cell Death Dis. 2017:8:e2750.

92. Hou CH, Chiang YC, Fong YC, Tang CH. WISP-1 increases MMP-2 expression and cell motility in human chondrosarcoma cells. Biochem Pharmacol. 2011;81:1286-95.

93. Yanagita T, Kubota S, Kawaki H, Kawata K, Kondo S, Takano-Yamamoto T, et al. Expression and physiological role of CCN4/Wnt-induced secreted protein 1 mRNA splicing variants in chondrocytes. FEBS J. 2007;274:1655-65.

94. Yu C, Le AT, Yeger H, Perbal B, Alman BA. NOV (CCN3) regulation in the growth plate and CCN family member expression in cartilage neoplasia. J Pathol. 2003;201:609-15.

95. Fong YC, Lin CY, Su YC, Chen WC, Tsai FJ, Tsai CH, et al. CCN6 enhances ICAM-1 expression and cell motility in human chondrosarcoma cells. J Cell Physiol. 2012;227:223-32.

96. Lin CY, Tzeng HE, Li TM, Chen HT, Lee Y, Yang YC, et al. WISP-3 inhibition of miR-452 promotes VEGF-A expression in chondrosarcoma cells and induces endothelial progenitor cells angiogenesis. Oncotarget. 2017:8:39571-81.

97. Tang Q, Jiang X, Li H, Lin Z, Zhou X, Luo X, et al. Expression and prognostic value of WISP-1 in patients with endometrial endometrioid adenocarcinoma. J Obstet Gynaecol Res. 2011;37:606-12.

98. Lin YH, Hsiao YH, Yang SF, Liu YF, Hsu CF, Wang PH. Association between genetic polymorphisms of WNT1 inducible signaling pathway protein 1 and uterine cervical cancer. Reprod Sci. 2018. https://doi. org/10.1177/1933719118756749.

99. Zheng M, Simon R, Kononen J, Sauter G, Mihatsch MJ, Moch H. Analysis of gene expression profiles among 3 epithelial ovarian tumor subtypes using cDNA and tissue microarrays. Ai Zheng. 2004;23:771-6.

100. Mason HR, Lake AC, Wubben JE, Nowak RA, Castellot JJ Jr. The growth arrest-specific gene CCN5 is deficient in human leiomyomas and inhibits the proliferation and motility of cultured human uterine smooth muscle cells. Mol Hum Reprod. 2004;10:181-7.

101. Bourdeau I, Antonini SR, Lacroix A, Kirschner LS, Matyakhina L, Lorang $D$, et al. Gene array analysis of macronodular adrenal hyperplasia confirms clinical heterogeneity and identifies several candidate genes as molecular mediators. Oncogene. 2004;23:1575-85.

102. Xie D, Nakachi K, Wang H, Elashoff R, Koeffler HP. Elevated levels of connective tissue growth factor, WISP-1, and CYR61 in primary breast cancers associated with more advanced features. Cancer Res. 2001;61:8917-23.

103. Banerjee S, Dhar G, Haque I, Kambhampati S, Mehta S, Sengupta K, et al. CCN5/WISP-2 expression in breast adenocarcinoma is associated with less frequent progression of the disease and suppresses the invasive phenotypes of tumor cells. Cancer Res. 2008;68:7606-12.

104. Dhar G, Banerjee S, Dhar K, Tawfik O, Mayo MS, Vanveldhuizen PJ, et al. Gain of oncogenic function of p53 mutants induces invasive phenotypes in human breast cancer cells by silencing CCN5/WISP-2. Cancer Res. 2008;68:4580-7.

Ready to submit your research? Choose BMC and benefit from

- fast, convenient online submission

- thorough peer review by experienced researchers in your field

- rapid publication on acceptance

- support for research data, including large and complex data types

- gold Open Access which fosters wider collaboration and increased citations

- maximum visibility for your research: over $100 \mathrm{M}$ website views per year

At BMC, research is always in progress.

Learn more biomedcentral.com/submissions 